\title{
Analysis Of Outside Claim Fragmentation On Bpjs Claims In Hospital
}

\author{
Tiny Rahayu, Mia Rahma Tika, Sapta Lestariyowidodo \\ Akademi Perekam Medis dan Informatika Kesehatan, Bandung, Indonesia \\ tinyrahyu2804@gmail.com, miarahmatika.mr@gmail.com, \\ Lestariyowidodo@gmail.com
}

Article Information
Submitted :14 Oktober
$\mathbf{2 0 2 1}$
Accepted : $\mathbf{1 6}$ Oktober
$\mathbf{2 0 2 1}$
Oline Publish : $\mathbf{2 8}$ Oktober
$\mathbf{2 0 2 1}$

Article Information

Abstract

The Social Security Organizing Agency (BPJS) has provisions regardingfraud in which one form of fraud is the breakdown of service episodes that are not in accordance with medical indications (serviceunbundling or fragmentation)it is done by health care providers in Health Facilities Referral Follow-Up (FKRTL) the action is done intentionally, to get financial benefits from public relations. Health Insurance program in the National Social Security System through fraudulent acts that are not in accordance with the provisions of the laws and regulations. The purpose of this study is to analyze the occurrence of Fragmentation in Hospital X. This research method uses quantitative methods from the data obtained. The results of this study of the Hospital conducted fragmentation in february 33 files and march 24 files and the number of fragmentation in mountax services. The hospital argued not to experience losses because the claim package that has been arranged by the Health Insurance Organizing Agency (BPJS) Instead of the Health Insurance Organizing Agency (BPJS) prohibits fragmentation because it includesfraud. In this study, the hospital can fragment because it is not applied standard operating procedures properly and in accordance with PERMENKES Number 16 of 2020 the hospital must have a fraud prevention team in order to conduct early detection.

Keywords: BPJS; JKN; Fragmentation; Claims; 


\section{Introduction}

Based on the Report to the Nations Acfe (RTTN) Association of Certified Fraud Examiners (ACFE) 2018 reports, losses due to fraud in health services reached 5\% of the total cost of health services. With the stipulation of Presidential Regulation Number 82 of 2018 concerning Health Insurance, it has provided a definition of fraud in the Health Insurance program, namely actions that are carried out intentionally, to obtain financial benefits from the Health Insurance program in the National Social Security System through fraudulent acts that are not in accordance with the provisions of the legislation.

The Social Security Administering Body (BPJS) has provisions in administering its health insurance which are contained in the Regulation of the Minister of Health of the Republic of Indonesia Number 16 of 2019 which then discusses the prevention and handling of fraud (fraud) and the imposition of administrative sanctions against fraud (fraud) in program implementation health insurance.

Fraud is an act that is carried out intentionally, to obtain financial benefits from the Health Insurance program in the National Social Security System (JKN) through fraudulent acts that are not in accordance with the provisions of laws and regulations (Perpres No 82 of 2018).

In the regulation, it has been stated that several fraudulent acts of the National Health Insurance (JKN) carried out by health service providers at the Follow-Up Referral Health Facility (FKRTL), one of which is solving service episodes that are not in accordance with medical indications (service unbundling or fragmentation) is a claim on two or more diagnoses and or procedures that should be part of a service package in the same episode.

This study attempts to analyze and describe how fraud claims in the outpatient department can occur against the claims of the Health Social Security Administering Body (BPJS) at Hospital X. based on the results of an interview with one of the informants of Hospital X, there were cases of fragmentation in January there were 38 cases out of 4027 patients with a claim fee of Rp. 7,220,000,-. Fragmentation of claims in Outpatients that occurs on average as a result of adjacent control schedules or it can also be called the breakdown of treatment episodes / Service unbundling or fragmentation and usually occurs in health services that are often affected by fragmentation, namely the part of the examination of supporting services at Mantoux Hospital X doing the solving episodes of treatment / Service unbundling or fragmentation in order to reduce hospital losses.

From the background and data obtained by the authors, the authors are interested in taking the title "Analysis of Outpatient Claim Fragmentation Against BPJS Claims at Hospital X". Therefore, this study aims to determine the flow and SOP (Standard Operating Procedure) claiming the National Health Insurance section. Outpatient at Hospital X, knowing the factors causing fragmentation (fraud) in Outpatient at Hospital $\mathrm{X}$, and also efforts to solve the problem of Outpatient Fragmentation carried out by Hospital X. 


\section{Method}

Methods This research method uses quantitative research methods with a descriptive approach. Quantitative research methods are research methods based on the philosophy of positivism, used to examine certain populations or samples, using research instruments, data analysis is quantitative/statistical, which aims to test established hypotheses (Sugiyono \& Kuantitatif, 2009, pp. 16-17)

The population is the entire element that will be used as the generalization area. The generalization area consists of objects/subjects that have certain quantities and characteristics determined by the author to be studied and can be concluded (Sugiyono, 2019: 126). In this study, a population of 57 files was used for 2 months.

The sample is part of the number and characteristics possessed by the population. If the population is large, and it is not possible for researchers to study everything in the population, for example due to limited funds, manpower and time, then samples taken from that population can be used by researchers (Sugiyono, 2019, p. 127).

Sampling technique is a sampling technique to determine the sample to be used in research, there are various sampling techniques used (Sugiyono, 2019, p. 128). In this study, the sampling technique used by the researcher is the census sampling technique or total sampling which is a sampling technique in which all members of the population are sampled entirely (Sugiyono, 2019, p. 134).

\section{Results and Discussion}

To answer the above problems, namely "Analysis of Outpatient Claim Fragmentation Against BPJS Claims at Hospital X":

\section{Standard Operating Procedures (SOP) and National Health Insurance Claims Flow}

Regarding the flow of claiming National Health Insurance for the Outpatient section at Hospital $\mathrm{X}$, the coding section provides coding results in the case mix section to be input into the ina-cbg application, the results are combined in a file to be given to BPJS (Social Security Administering Agency) sheets such as resumes, patient eligibility letters (SEP), and scanned LIP. Furthermore, it is verified by BPJS (Social Security Administration Agency) if there are cases pending, namely cases that are returned to the hospital because they require confirmation of the services that have been provided with the suitability of the code billed, among the pending cases, among others, are cases of fragmentation. 


\begin{tabular}{|c|c|c|c|}
\hline \multirow{3}{*}{$\begin{array}{l}\text { X Hospital } \\
\text { JL.XXX } \\
\text { Tel.XXX } \\
\text { Fax. XXX } \\
\text { Standard Operational } \\
\text { Procedures for }\end{array}$} & \multicolumn{3}{|c|}{ SUBMITTING CLAIMS BPJS } \\
\hline & $\begin{array}{l}\text { No. Document } \\
\text { 02.03.09.10.18 }\end{array}$ & No. Revision 1 & Page $1 / 3$ \\
\hline & $\begin{array}{l}\text { Publish Date } \\
\text { August } 2018\end{array}$ & \multicolumn{2}{|c|}{ Authorized By Hospital Director X } \\
\hline DEFINITION & \multicolumn{3}{|c|}{$\begin{array}{l}\text { Procedure for submitting claims for BPJS RS.X patients against BPJS } \\
\text { claims }\end{array}$} \\
\hline PURPOSE & \multicolumn{3}{|c|}{$\begin{array}{l}\text { To support the achievement of orderly administration for BPJS } \\
\text { Kesehatan Hospital X patients. }\end{array}$} \\
\hline POLICY & \multicolumn{3}{|c|}{ MOUbetween RS.X and BPJS Kesehatan } \\
\hline PROCEDURE & \multicolumn{3}{|c|}{ Submission of Outpatient Claims } \\
\hline
\end{tabular}

X Hospital
JL.XXX
Tel.XXX
Fax. XXX

\section{SUBMITTING CLAIMS BPJS}

\begin{tabular}{|l|l|l|}
\hline $\begin{array}{l}\text { No. Document } \\
\text { 02.03.09.10.18 }\end{array}$ & No. Revision 1 & Page 2/3 \\
\hline
\end{tabular}

a) Outpatient supporting files in the form of Referrals, Resume, Outpatient SEP, Support (Lab, Radiology, Pharmacy) are collected in the Outpatient section.

b) File coding is done by the coder.

c) Input files and print LIP (Patient Individual Sheet).

d) File Scan.

e) Checking outpatient files by date.

f) File numbering.

g) Sending files to the BPJS office.

2. Submission of Inpatient Claims

a) Completeness of Inpatient supporting files in the form of Referrals, Resume, Inpatient SEP, Support (Radiology Lab, Pharmacy) are collected in the Inpatient section.

b) File coding is done by the coder.

c) File input and print LIP (Patient Individual Sheet).

d) File scans.

e) Checking hospital files.

f) File numbering.

g) Sending files to the BPJS office. 


\section{Factors Causing Fragmentation (Fraud)}

Factors causing fragmentation (fraud) in Outpatient Hospital X, obtained the following data:

\begin{tabular}{l|l|l|l} 
Month of Service & Fragmentation Case & $\begin{array}{l}\text { Number of patient } \\
\text { visits }\end{array}$ & \% Fragmentation \\
\hline February & 33 File & 3,995 & $0,82 \%$ \\
\hline March & 24 Files & 3,832 & $0.62 \%$
\end{tabular}

Table 1. Fragmentation Case Data

\section{Source: Researchers}

Fragmentation data was obtained in February, there were 33 cases of fragmentation from 3,995 patients and in March there were 24 files from 3,832 patients according to Table 1. What happened in the field of fragmentation was mostly in Mountax services.

\section{Outpatient Fragmentation Problem Solving}

Efforts to solve the Outpatient Fragmentation problem carried out by Hospital X, from interviews conducted by researchers with one of the informants at Hospital X, the solution is to hold a meeting or if pending again the Hospital chooses to acknowledge and accept that The case is fragmented.

\section{Conclusion}

Based on the results of the research and the author's discussion at Hospital X. At Hospital $\mathrm{X}$ the claim flow has been running but does not implement the Standard Operating Procedures for claims properly. The factors that cause Fragmentation in Hospital X are because, The absence of a Fraud Prevention Team whose function is to detect fraud cases early, which ultimately results in the hospital committing violations, namely Fragmentation. Efforts made by the hospital are holding negotiations with the case mix section. Lack of ability of case mix workers in claiming rules, because case mix sections have just been created. Reports that are not carried out properly. Solutions carried out by the hospital have been carried out but are less effective because they do not solve the problem. 
Tiny Rahayu, Mia Rahma Tika, Sapta Lestariyowidodo/KESANS

Analysis Of Outside Claim Fragmentation On Bpjs Claims In Hospital

\section{BIBLIOGRAFI}

Hartati, T. S., Sakit, R., Daerah, U., \& Tulang, M. (2016). PENCEGAHAN KECURANGAN ( FRAUD ) DALAM PELAKSANAAN PROGRAM JAMINAN KESEHATAN PADA SISTEM JAMINAN SOSIAL KESEHATAN ( SJSN ) DI RUMAH SAKIT UMUM DAERAH MENGGALA. 10(4), 715-732.

Kurniawan, S., Disemadi, H. S., \& Purwanti, A. (2020). Urgensi Pencegahan Tindak Pidana Curang ( Fraud) Dalam Klaim Asuransi Urgency of Fraud Prevention in Insurance Claims. 4(1), 38-53.

Mitriza, A., Akbar, A., \& Base, C. (n.d.). Artikel Penelitian Analisis Pengendalian Potensi Fraud di Rumah Sakit Umum Daerah Achmad Moechtar Bukittinggi. 8(3), 493-499.

Petunjuk Teknis Pengklaiman Badan Penyelenggaraan Jaminan Sosial Kesehatan

PERATURAN BADAN PENYELENGGARA JAMINAN SOSIAL NOMOR 3 TAHUN 2020

PERATURAN MENTERI KESEHATAN NOMOR 16 TAHUN 2019 tentang Pencegahan Dan Penanganan Kecurangan (Fraud) Serta Pengenaan Sanki Administrasi Terhadap Kecurangan (Fraud) Dalam Pelaksanaan Program Jaminan Kesehatan.

PERATURAN PRESIDEN NOMOR 82 TAHUN 2018 tentang Jaminan Kesehatan Nasional

Program, D., \& Medis, R. (2020). PENYUSUNAN ARTIKEL ILMIAH.

Rakha, R., Trimanda, A., No, J. G., Siliwangi, L., Bandung, K., \& Barat, J. (2018). KESEHATAN UNTUK PENDETEKSIAN FRAUD ( STUDI KASUS: BPJS KESEHATAN ). November.

Rsj, D. I., \& Wediodiningrat, R. (2014). KESEHATAN NASIONAL TERHADAP MUTU LAYANAN. 03(04), 183-191.

Sadikin, H., \& Adisasmito, W. (2016). Analisis Pengaruh Dimensi Fraud Triangle Dalam Kebijakan Pencegahan Fraud Terhadap Program Jaminan Kesehatan Nasional di RSUP Nasional Cipto Mangunkusumo. 1, 28-34.

Sugiyono, 2019, Metode Penelitian Kuantitatif, Kualitatif dan R\&D, Bandung : Alfabeta 